\title{
NETIZEN JURNALISME DAN TANTANGAN DAKWAH \\ DI MEDIA BARU
}

\author{
Mokhamad Abdul Aziz \\ Pendiri Azmi Center, Mahasiswa Program Pascasajana Universitas Diponegoro (UNDIP) \\ Semarang. \\ mokhamadabdulaziz@gmail.com
}

\begin{abstract}
$O$ ld media changes to new media followed by a new culture of information society. They invade the internet with various complexities. This has strengthened the culture of citizen journalism that has emerged several years before. This era called the era of netizen journalism, which hopes can provide great benefits to society. However, currently inevitable, the negative impact of the internet is so real, as evidenced by the many violations and abuse. The lack of understanding or limited knowledge of netizens regarding ethics and principles that must be used in social media, the adverse effects on users cannot be avoided. Therefore, comprehensive media literacy and contestation is needed to explore all netizens to understand netiquette in new media. Now netizens have even had Social media to be used as a means of preaching. Scholars looking for a surefire strategy format to preach in social media.
\end{abstract}

Keywords: netizen journalism, netiquette, preaching. new media

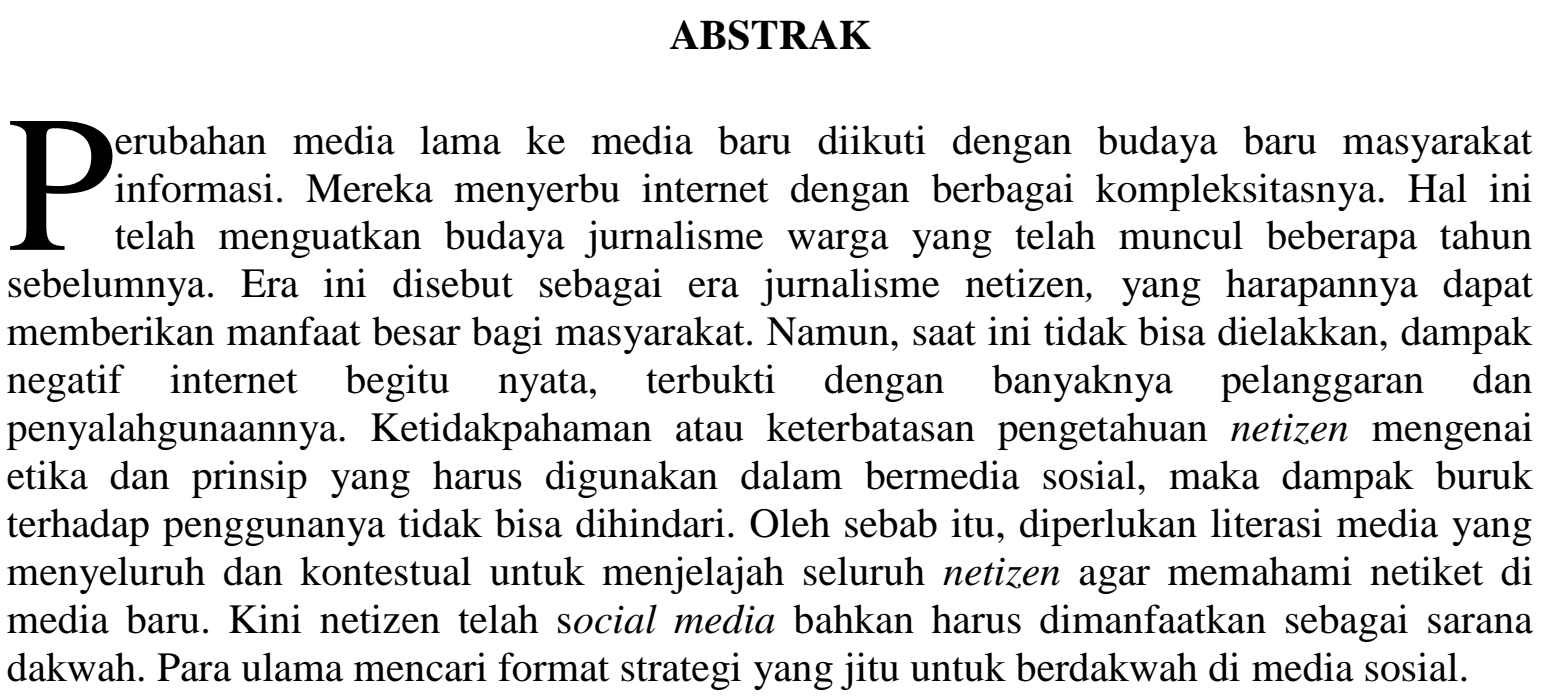

Kata kunci: jurnalisme netizen, netiket, dakwah, media baru

Islamic Comunication Journal

Volume 3, Nomor 2, Juli-Desember 2018 


\section{PENDAHULUAN}

Manusia merupakan makhluk sosial, yaitu makhluk yang tidak bisa hidup sendiri. Aristoteles, sebagaimana dikutip Ahmad Suhelmi (2007: 24), menyebutnya dengan istilah zoon politicon (makhluk yang berpolitik). Konsekuensi logis dari makhuk sosial itu adalah adanya saling interaksi antara manusia satu dengan manusia lainnya. Dalam interaksi tersebut, ada satu hal yang tidak bisa dihindari dan dilepaskan, yaitu komunikasi. Maka tidak heran jika Watzlawick, Beavin, dan Jackson mengatakan, "We cannot not communicate!, (Kita tidak bisa, tidak berkomunikasi)". Itu artinya, manusia tidak bisa menghindari komunikasi. Bahkan ketika diam, seseorang itu juga sedang ber-komunikasi. Ketika pejabat mengatakan, "no comment", maka ia sebetulnya menyampaikan komunikasi kepada publik, sehingga manusia perlu berkomunikasi untuk menghindari komunikasi (Rakhmat, 1998: 76).

Manusia, yang dalam ilmu logika didefinisikan sebagai hayawan al-natiq (hewan yang berlogika/berbicara), mempunyai keunggulan dalam hal berkomunikasi (tentu semua hewan berinteraksi dan berkomunikasi-menurut cara mereka masing-masing). Manusia memiliki cara dan etika yang berbeda dalam berkomunikasi dengan yang lain. Etika komunikasi itulah yang akan membuat seorang manusia itu dipandang baik atau buruk oleh sesamanya. Seseorang yang meniadakan etika dalam berkomunikasi secara tidak langsung justru akan menempatkan dirinya ke dalam stigma negatif, misalnya akan dianggap tidak berpendidikan, tidak punya sopan santun, atau bahkan tidak punya akal dan hati (Aziz, 2014: 2). Jika yang terjadi demikian, maka yang menjadi pertanyaan adalah apa perbedaan manusia dengan hewan. Inilah hal penting yang perlu diperhatikan dan dimengerti.

Bentuk dan pola komunikasi sendiri, dari waktu ke waktu, selalu mengalami perubahan,menyesuaikan dengan perkembangan zaman. Ketika dunia kini telah memasuki era digitalisasi, komunikasi juga mengalami perkembangan yang sangat mencolok dan signifikan. Komunikasi tidak lagi dipahami secara sederhana dan klasik yang mensyaratkan adanya tatap muka dan suara (pesan) yang dipertukarkan. Akan tetapi, seiring dengan perkembangan ilmu pe-ngetahuan dan teknologi, komunikasi berkembang mengikutinya, tentu saja dengan bentuk dan pola yang berbeda. Apalagi sejak muncul dan berkembang pesatnya internet, yang kemudian disebut new media (media baru), komunikasi menjadi sangat dinamis dan complicated. Karena itulah, Wynants dan Cornelis (2008: 13) mengemukakan bahwa internet membuka sebuah dunia baru yang penuh keterbukaan. Sebuah dunia yang menawarkan harapan dengan pemenuhan kebutuhan yang positif sekaligus ancaman dengan segala dampak negatifnya.

Kemudian dari pada itu, internet sebagai media komunikasi dengan kemampuan konvergensinya hadir sebagai suatu bentuk media baru yang mendominasi saat ini. Internet yang memiliki dasar opensource semakin menarik minat banyak orang untuk berpartisipasi dalam media baru ini. Salah satu caranya adalah dengan menggunakan 
media sosial yang sedang marak sekarang ini: Facebook, Twitter, Instagram, dan Path, misalnya. Media sosial ini memanfaatkan internet untuk menciptakan suatu ruang publik baru yang lebih besar dan luas daripada ruang publik yang telahada sebelumnya (Wynants dan Cornelis, 2008: 13). Sejak itu, teori-teori yang membahas bentuk-bentuk komunikasi; intrapersonal, interpersonal, kelompok, dan komunikasi massa, menjadi tidak semudah sebelumnya digunakan untuk memahami komunikasi yang terjadi pada masyarakat internet (baca: warganet).

Pada dasarnya, teknologi memiliki kontribusi dalam menciptakan keberagaman media. Dari sisi industri, biaya produksi media dan alat produksi yang semakin murah dan canggih menyebabkan kemunculan media secara massal. Teknologi memungkinkan industri media untuk memproduksi media lebih beragam, kondisi ini bisa dilihat dari konvergensi media yang tidak hanya berada dalam bentuk cetak semata, tetapi juga khalayak bisa menemukan media yang sama dalam bentuk elektronik. Tidak hanya dari sisi jumlah, tetapi juga khalayak diberikan pilihan untuk mengonsumsi melalui jenis medianya mulai dari cetak, audio, visual, audiovisual, hingga online (Nasrullah, 2014: 1).

Media baru menyatukan semua yang dimiliki media lama. Jika surat kabar hanya dapat dibaca dalam media kertas, radio hanya dapat didengar, televisi hanya menyatukan audio dan visual, melalui internet semua itu dapat disatukan baik tulisan, suara dan gambar hidup. Pengguna internet kini dapat membaca tulisan melalui blog, website, dapat mendengarkan radio melalui radio internet, dapat menonton siaran berita melalui live streaming atau mengunduh video. Dengan kata lain, semua karakteristik khas masing-masing old media dapat disatukan dalam dunia new media (Tamburaka, 2013: 77).

Pada era informasi saat ini, yang menjadi penguasa dunia adalah mereka yang menguasai informasi dan perangkat teknologi informatika, sebagaimana yang diprediksi oleh Alvin Toffler (19281996). Sebagai pilar keempat (the fourth state) dalam sistem politik-ekonomi, pers dan jurnalistik memiliki fungsi, yaitu sebagai penyalur aspirasi rakyat, pembentuk kecenderungan (trend setter) pendapat masyarakat, kelompok penekan (presure group) yang dapat turut mempengaruhi dan mewarnai kebijakan politik negara (public decision making), dan pembela kebenaran dan keadilan (Samantho, 2002: 64).

Media adalah pusat kendali, tidak hanya kemampuan teknologinya melampaui ruang dan waktu, melainkan juga karena saling keterhubungannya yang melekat dengan komunikasi, khususnya kapasitasnya untuk memberi individu akses pada jaringan global (global networks). Sebagai bagian dari perkembangan teknologi informasi yang pesat, kehadiran internet beserta berbagai situs atau konten yang ada di dalamnya tidak hanya merubah perilaku individu, melainkan juga pada tingkat kelompok bahkan dalam skala yang semakin mengglobal (Sugihartati, 2014: 95). Keadaan ini memberikan dua peluang sekaligus, yakni semakin cepat dan mudahnya peluang transformasi nilai-nilai positif dan juga peluang menyebarnya 
nilai dan kehendak negatif dalam masyarakat.

Sisi positif berkembangnya media internet, salah satunya, adalah memudahkan kegiatan komunikasi dan jurnalistik, baik bagi pihak profesional maupun warga biasa. Harus diakui, saat ini masyarakat dan pengguna internet terdorong untuk ikut berpartisipasi dalam aktivitas jurnalistik. Aktivitas ini pada akhirnya semakin menumbuhkembangkan kegiatan citizen juornalism yang pada mulanya bergelora di Amerika Serikat. ${ }^{1}$ Media internet tidak hanya menjadi media warga untuk mengakses berita dan informasi, tetapi juga digunakan wargauntuk menulis dan mempublikasi berita atau opini yang mereka buat untuk khalayak. Di era media sosial saat ini, bahkan tidak cuma peristiwa dan isu yang dapat ditulis dan disebarkan sebagai produk jurnalistik, tetap lebih dari itu, media sosial lebih tepat dikatakan sebagai wadah setiap orang mengekspresikan kehidupan jiwanya. Sebab, apa yang menjadi pengalamanhidupnya dapat diekspos oleh dirinya sendiri, suka dan duka yang dialami.

Media sosial juga menjadi wadah bagi masyarakat untuk menggalang kekuatan sosial,melakukan pergerakan sosial.

${ }^{1}$ Citizen Journalism atau dikenal jurnalisme warga mulai berkembang pada tahun 1988 pada saat pemilihan Presiden Amerika Serikat. Jay Rossen, dosen Universitas New York memperkenalkan genre jurnalistik kepada warga Amerika Serikat. Padahal saat itu internet masih merupakan barang langka. Media jurnalisme warga yang paling fenomenal adalah OhmyNews yang berpusat di Korea Selatan. Setiap hari memuat sedikitnya 300 berita dari seluruh dunia. Sekarang OhmyNews memiliki edisi bahasa Inggris dengan kontributor tetap sekitar 1000 orang dari sekitar 100 negara (Kuswarno dkk, 2010: 469).
Media sosial memang tidak lagi menjadi life style melainkan need, dengan berbagai tujuan dan kepentingan. Karena itu, seringkali ditemukan terjadicyber war, terutama dalam masa-masa pemilihan umum ini. Ujaran kebencian (hate speech) dari para pengguna social media - baik itu untuk menghina dan merendahkan orang yang menjadi rival yang didukung maupun sentimen pribadi terhadap orang lain-menjadi problem baru saat ini sekaligus menunjukkan dampak negatif internet dalam masyarakat. Tentu saja bukan salah internet, tetapi lebih pada penggunanya, karena sesungguhnya internet merupakan benda mati yang dampaknya tergantung kepada siapa penggunanya.Hal demikian terjadi, karena tidak terlepas dari faktor pengetahuan pengguna (user) dalam memanfaatkan media.

Media sosial menghadirkan "bara" baru di tengah kebebesan berpendapat yang tengah menggebu di Indonesia pascareformasi. Akan tetapi, perlu disadari bahwa walaupun itu akun pribadi, harus tetap dipertanggungjawabkan. Jika tidak, ini tentu akan persoalan yang tidak menyenangkan hingga membawa dalam situasi pada kehidupan nyata yang tidak sederhana, yang tidak jaramg menjadi permasalahan hukum. Permasalahan etika komunikasi dalam ruang dunia maya seringkali menjadi permasalahan serius karena tak jarang kalimat yang ditulis pada akun menimbulkan kata-kata pedas yang tak pantas dituturkan itu berlanjut ke ranah peradilan.Regulasi hukum pun dibuat untuk mengaturnya, yakniUndangUndang Nomor 11 Tahun 2008 tentang Informasi Transaksi Elektronik (ITE). Penegakan hukum pun ditegakkan. Satu

\section{4


contoh, mantan anggota DPR 1999-2004, Hatta Taliwang, ditangkap penyidik Polda Metro Jaya pada Kamis (8/12/2016) pagi. Hatta Taliwang dijerat UU ITE dengan kaitan dugaan Pasal 28 Ayat (2) juncto Pasal 45 UU ITE (Okezone, 8 Desember 2016). Apalagi pasca mencuatnya kasus dugaan penistaan agama oleh Basuki Tjahaja Purnama alias Ahok, hampirhampir kegaduhan demi kegaduhan mewarnai media sosial selama lebih dari satu tahun. Ini menjadi fenomena baru di Indonesia yang menarik untuk dipelajari lebih dalam.

Keadaan yang demikian sudah semestinya menjadikan semua pihak menyadari akan pentingnya etika dalam menggunakan media, terlebih media sosial yang sangat bebas itu. Salah satu yang diminta turun tangan adalah ulama. Para pewaris para nabi itu dituntut untuk mengembangkan dakwah dan pendidikannya melalui media sosial. Hal ini dikemukakan oleh Ketua Komisi Dakwah MUI Jateng KH Nadhom Asror saat menghadiri Halaqoh Ulama di Semarang. Asror menyatakan bahwa sudah seharusnya para ulama memanfaatkan medsos sebagai media dakwah (Harian Amanah, 29 Desember 2016) Namun, bukan berarti hal ini semata-mata mudah untuk dilakukan. Ada banyak tantangan yang harus disadari dan dihadapi para ulama ketika memutuskan untuk "terjun" dakwah di media sosial.

Dengan latar belakang yang demikian itu, penulis melakukan library research dengan menggunakan metode analisis deskriptif kritis, yaitu suatu usaha untuk mengumpulkan dan menyusun suatu data kemudian diadakan analisis, sehingga dapat memberi gambaran yang komprehensif (Suratman, 1985: 139). Tulisan ini sebagai refleksi yang mengungkap bagaimana seharusnya netizen memahami dan menggunakan media internet sebagai media jurnalistik, perlunya literasi media dan etika warganet, serta bagaimana tantangan dakwah era global dan penulis akan menyoroti peran ulama dalam berdakwah menggunakan media sosial.

\section{New Media dan Netizen Jurnalism}

Sebelum membahas lebih detail mengenai New Media dan Netizen Jurnalism, ada baiknya memahami bagaimana konsep media komunikai secara umum. Media adalah suatu sarana yang dapat digunakan untuk menyampaikan informasi kepada seseorang. Media berasal dari bahasa Latin dan merupakan bentuk jamak dari kata medium yang secara harfiah berarti "perantara" yaitu perantara sumber pesan (a source) dengan penerima pesan (a receiver) (Hermawan, 2007: 3).Kata media dalam bahasa Arabadalah wasaai yang berarti perantara atau pengantar pesan dari pengirim kepada penerima pesan (Arsyad, 2002: 4).

Para pengkaji media dan budaya kritis telah menggunakan beberapa pendekatan untuk memahami arti penting sosiokultural media dalam kehidupan seharihari dengan menhadirkan istilah-istilah kunci: media sebagai pembentuk, cermin, pengemas, guru, ritual, atau bahkan "Tuhan"(Ibrahim, 2014: 3). Hal ini membuktikan bahwa media menciptakan dan mempengaruhi cakupan serta bentuk hubungan-hubungan dan kegiatan- 
kegiatan manusia. Pengaruh media telah berkembang dari individu kepada masyarakat. Dengan media, setiap bagian dunia dapat dihubungkan menjadi global village (desa global).Inilah yang kemudian dikenal dengan teori determinisme teknologi (McLuhan); seseorang percaya bahwa semua perubahan kultural, ekonomi, politik, dan sosial secara pasti berlandaskan pada perkembangan dan penyebaran teknologi (Tamburaka, 2013: 71).

Menurut Graeme Burton, istilah 'media' berlaku bagi produk-produk informasi dan hiburan dari industriindustri media, begitu juga contoh-contoh telekomunikasi yang membantu membawakan produk-produk tersebut kepada masyarakat informasi (Burton, 2012: 27). Sedangkan menurut David Holmes, istilah media itu sendiri, yang secara tradisional berpusat pada gagasan tentang media massa, dikemukakan di Amerika Serikat oleh disiplin 'komunikasi massa'. Akan tetapi, studi-studi media (dan studi-studi komunikasi massa) dalam bentuk tradisionalnya tidak dapat lagi membatasi dirinya pada dinamika broadcast(Homes, 2012: 14).Media telah meninggalkan budaya tradisionalnya menuju era internet (second media age) atau yang kemudian disebut sebagai media baru (new media).Era ini menawarkan warna baru dengan efek yang tidal kalah berwarnanya.

Burhan Bungin (2011: mengemukakan beberapa pendapat tokoh terkait dengan hal ini, sebagai berikut: Everett M. R'ogers (1986) dalam buku Communication Technology; The New Media in Society, mengatakan bahwa dalam hubungan komunikasi di masyarakat, dikenal empat era komunikasi, yaitu: era tulis, era media cetak, era media telekomunikasi, dan era media komunikasi interaktif. Dalam era terakhir media komunikasi interaktif dikenal media computer, videotext, dan teletext, teleconferencing, TV kabel, dan sebagainya.Sementara itu Sayling Wen (2002) dalam bukunya Future of the Media, melihat media dalam konteks yang lebih luas, tidak saja melihat media dalam konsep komunikasi antar-pribadi, namun juga melihat media sebagai medium penyimpanan, selain ia melihat media sebagai medium informasi. Enam media hubungan antarpribadi yang dimaksud oleh Wen adalah suara, grafik, teks, music, animasi, video. Sedangkan media penyimpanan adalah buku dan kertas, kamera, alat perekam kaset, kamera film dan proyektor, alat perekam video dan disk optikal.

Adanya perkembangan teknologi informasi telah memicu perubahan besar dalam teknologi digitalisasi, yang memperlihatkan semua konten media, baik cetak maupun elektronik dapat digabungkan dan didistribusikan (Tamburaka, 2013: 72). Inilah era media baru, media yang menghadirkan dunia baru dengan segala dinamikanya. New Media atau media online didefinisikan sebagai produk dari komunikasi yang termediasi teknologi yang terdapat bersama dengan komputer digital (Creeber G. dan Martin, 2009). Definisi lain media online adalah media yang di dalamnya terdiri dari gabungan berbagai elemen. Dengan kata lain, terdapat konvergensi media di dalamnya, dimana beberapa media dijadikan satu (Lievrouw, L.A. dan Sonia Livistone, 2006). New media 
merupakan media yang menggunakan internet, media online berbasis teknologi, berkarakter fleksibel, berpotensi interaktif dan dapat berfungsi secara privat maupun secara publik (Mondry, 2008: 13). Dengan demikian, dapat diapahami bahwa media baru masyaratkan adanya internet.

Internet adalah salah satu bentuk dari new media. Internet muncul di pertengahan 1990 an sebagai medium massa baru yang amat kuat. Menurut John Vivian, internet adalah jaringan kabel, telepon, dan satelit yang menghubungkan computer. Hampir semua orang di planet ini yang memiliki computer bisa masuk ke jaringan. Di situlah lautan informasi dan hiburan bisa diakses dengan sangat mudah (Vivian, 2015: 262). Lautan yang menghadirkan pemandangan indah nan menakjubkan sekaligus bisa mendatangkan gelombang yang besar nan menghancurkan.

Internet dinilai sebagai alat informasi paling penting untuk dikembangkan kedepannya. Internet memiliki kemampuan untuk mengkode, menyimpan, memanipulasi dan menerima pesan (Brent Ruben dan Lea P. Stewart, 1998: 110). Internet merupakan sebuah media dengan segala karakteristiknya. Internet memiliki teknologi, cara penggunaan, lingkup layanan, isi dan image sendiri. Internet tidak dimiliki, dikendalikan atau dikelola oleh sebuah badan tunggal tetapi merupakan sebuah jaringan komputer yang terhubung secara intensional dan beroperasi berdasarkan protokol yang disepakati bersama. Sejumlah organisasi khususnya provider dan badan telekomunikasi berperan dalam operasi internet (McQuail, 2009: 28-29).
Novia Ika Setyanidengan mengutip pendapat Septiawan Santana Kurnia menyatakan, internet adalah sebuah medium terbaru yang mengkonvergensikan seluruh karakteristik media dari bentuk-bentuk yang terdahulu. Apa yang membuat bentuk-bentuk komunikasi berbeda satu sama lain bukanlah penerapan aktualnya, namun perubahan dalam proses komunikasi seperti kecepatan komunikasi, harga komunikasi, persepsi pihakpihak yang ber-komunikasi, kapasitas storage dan fasilitas mengakses informasi, densitas (kepekatan atau kepadatan) dan kekayaan arus-arus informasi, jumlah fungsionalitas atau intelijen yang dapat ditransfer. Jadi menurut Santana, titik esensinya adalah bahwa keunikan internet terletak pada esensinya sebagai sebuah medium (Setyani, 2013: 5)

Perubahan media lama ke media baru membawa peruabahan dalam media massa dan jurnalisme. Perubahan teknologi ternyata membawa perubahan sangat besar dalam aktivitas jurnalisme, batasan geografis menjadi kecil-desa global internet-termasuk mereka yang berpartisipasi yakni kelompok anak muda setiap saat melakukan aktivitas jurnalisme online, termasuk inovasi dalam teknologi ini, bukan hanya tulisan yang dapat dipampang, berita pun secara individu dapat disebarluaskan atau dibagi dengan media (Tamburaka, 2013: 73). Hal ini mendorong dan menguatkan aktivitas citizen Journalism atau dikenal jurnalisme warga mulai berkembang sebelum internet muncul, yakni pada tahun 1988, tepatnya saat pemilihan Presiden Amerika Serikat.

Di Indonesia, cikal bakal citizen journalism mulai muncul ketika peristiwa

Islamic Comunication Journal Volume 3, Nomor 2, Juli-Desember 2018 
tsunami melanda Aceh.Seorang warga yang berhasil merekam detik-detik terjadinya tsunami tersebut melalui video amatir kemudian dipublikasikan di berbagai media di dalam negeri dan luar negeri. Rekaman yang tersebar inipun hampir menggantikan peran jurnalis professional yang pada saat itu tidak mendapati peristiwa secara langsung. Apa yang telah dilakukan warga tersebut merupakan jurnalisme warga, yaitu aktivitas peliputan berita yang dilakukan oleh warga dari tempat kejadian. Menurut Jay Rosen bahwa citizen journalist adalah "the people formerly known as the audience, who were on the receiving end of a media system that ran one way, in a broadcasting pattern, with high entry fees and a few firms competing to speak very loudly while the rest of the population listened in isolation from one another-and who today are not in a situation like that all, the people formerly known as the audience are simply the public made realer, less fictional, more able less predictable." Pada dasarnya citizen journalism (jurnalisme warga) dikenal juga khalayak atau audien sebagai bagian dari rantai berita media yang mampu menyuarakan secara jelas aspirasinya secara sederhana (Tamburaka, 2013: 244).

Di Indonesia, citizen journalism lebih menonjol di ranah sosial dan hukum, kurang berjalan baik di ranah politik. Bisa jadi karena para netizen di Indonesia tidak berminat pada dunia politik. Di ranah sosial dan hukum, pilar kelima menunjukkan kekuatannya, para facebooker dan twitter berhasil memengaruhi dibatalkannya gugatan hukum terhadap dua pimpinan KPK yaitu Bibit Samad dan Chandra Hamzah dengan gerakan "sejuta tanda tangan". Para facebooker dan twitter juga berhasil menggalang dana "Koin untuk Prita", sehingga Prita dapat membayar dendanya dari kasus perdata (Prita kalah dalam pengadilan melawan para dokter dan RS Omni Internasional Tangerang) (Syah, 2014: 15).

Warga yang terlibat di dalam media citizen journalism tidak hanya sebagai konsumen dari produk, tetapi juga sudah menjadi produsen, pengembang, kreator. Fenomena yang berbeda jika melihat posisi warga di dalam media tradisional (baca: konvensional) seperti koran, televisi, maupun radio. Dalam hal ini warga menjadi audien atau sebagai konsumen pasif, karena media merupakan milik produsen. Warga hanya bisa menerima apa yang telah diberikan oleh media massa. Seiring dengan meningkatnya penggunaan internet jenis jurnalisme, kemudian berkembang yaitu jurnalisme warga yang melibatkan warga masyarakat untuk ikut berperan mengisi media.

Menurut Aceng Abdullah, semakin maraknya jurnalisme warga disebabkan oleh sejumlah faktor, di antaranya: pertama, berbagai informasi yang dibutuhkan khalayak tidak selalu terpenuhi oleh media massa konvensional. Kedua, khalayak bukan hanya butuh informasi, tetapi juga butuh menginformaskan fakta dan opininya. Ketiga, khalayak memiliki foto atau rekaman gambar yang jauh lebih bagus daripada yang dimiliki media massa umum (Bajari dan Sahala TS, 2011: 470). Lebih dari itu, dalam konteks politik yang sarat akan kepentingan, jurnalisme warga tumbuh dan berkembang bak jamur di 
musim hujan. Hal ini semakin menguatkan partisipasi warga negara dalam memperkuat demokrasi patisipatif.

Keberdayaan yang semakin menguat dari masyarakat dunia maya mengingatkan pada adagium Marshal McLuhan "the medium is the message". Makna isi pesan dipengaruhi medium pengantarnya. Medium internet menggarisbawahi kebenaran teori tentang karakter khalayak media: berjumlah besar, anonim, heterogen, mengontrol atau mengendalikan. Khalayak dunia maya tidak terhitung jumlahnya, khalayak heterogen dan jelas memiliki kontrol atau kendali atas isi media. Hasil survei Facebook Kadin menunjukkan publik berkehendak dan berdaya menentukan arah pemberitaannya sendiri (Syah, 2014: 16).

Fenomena keberadaan internet dewasa ini menunjukkan adanya perubahan besar dalam komunikasi massa. Media massa lama/konvensional (surat kabar, radio, televisi) bukan lagi satusatunya sumber daya informasi. Kehadiran internet bagi pengguna merupakan sebuah media baru yang menawarkan keberagaman dan kebebasan akan akses informasi bagi pengguna tanpa harus terikat pembatasan dan sensor. Banyaknya dan beragamnya informasi di internet menjadi sumber baru yang menarik khalayak media massa untuk berpindah dari media massa lama ke media baru(internet). Pergeseran teknologi tradisional ke teknologi digital juga membawa perubahan besar dalam cara manusia berkomunikasi (Tamburaka, 2013: 72). Kegiatan jurnalisme yang dilakukan oleh masyarakat internet

(netizen) inilah yang kemudian disebut sebagai netizen journalism.

Istilah netizen journalism digunakan oleh Ronda Hauben (2014) dalam artikelnya bertajuk "Netizen Journalism: The Emergence of New Forms of News that Can Improve the Policy Making Process". Hauben mengajukan beberapa pertanyaan untuk menguji kebaruan dan signifikansi istilahnya: 1) What is this new form of news and what are its characteristics? 2) Is this something different from traditional journalism? 3) Is there some significant new aspect represented by netizen journalism?Aktivitas jurnalisme yang dilakukan oleh warga internet terbukti menjadi alternative dalam memberikan varian informasi terkait suatu hal, peristiwa, atau kasus.

Banyak penelitian tentang jurnalisme yang bersangkutan dengan unsur menciptakan dan menyebarkan narasi, dengan konsep seperti "framing", "agenda setting" dan "news difution" menyediakan sarana untuk menganalisis dan memahami proses yang merupakan komponen dari berita proses. Misalnya, jika framing dari berita bergantung pada pejabat pemerintah atau perusahaan yang kuat, cerita ini mungkin akan berbeda secara signifikan dengan framing yang berfokus pada perspektif korban beberapa penyalahgunaan oleh pemerintah atau entitas perusahaan (Touri, 2009: 177).

Secara tradisional, pers dapat berfungsi sebagai pengawas bagi masyarakat dengan mengekspos penggunaan dan penyalahgunaan kekuasaan. Sebaliknya, pers dapat bertindak untuk mendukung penyalahgunaan kekuasaan politik. Jika 
netizen jurnalisme dapat memberikan pemahaman yang lebih akurat mengenai konflik, maka akan dapat lebih membantu membuat resolusi damai dari konflik tersebut (Hauben, 2014).

Terbukanya akses terhadap informasi yang disediakan oleh citizen journalism, diyakini akan dapat memberikan manfaat besar bagi masyarakat. Bagaimanapun, karena orang-orang yang melakukan aktivitas citizen journalism bukan merupakan jurnalis terlatih, terdapat kemungkinan bahwa informasi yang disiarkan menggunakan bahasa polos dan tanpa melalui proses editing (Syarifah, 2015: 28).Namun, bukan berarti budaya baru di media baru ini tidak menimbulkan masalah baru. Fitri (2016: 246) mengutip pendapat Tamburaka, setidaknya, ada 4 yang menjadi masalah dalam operasional jurnalisme yang dilakukan oleh warga, teruama netizen: 1) Fakta informasi. 2) Akurasi data. 3) Pertanggungjawaban pembuat berita. 4) Etika media. Masalahmasalah tersebut akan lebih berbahaya intensifikasinya jika netizen itu di media sosial. Akan ada umpan balik seama netizen secara langsung, yang tidak jarang berakibat pada keluarnya ujaran kebencian (hate speech), saling hina dan hujat,dan hal lain yang dapat merusak marwah per situ sendiri. Karena itu, perlu penyelesaian secara menyeluruh terhadap ini.

\section{Literasi Media dan Netiket di Media Baru}

Masalah-masalah yang ada pada media baru, mulai dari penggaran etika sampai kepada penyalahgunaan media tentu tidak bisa dibiarkan begitu saja.
Menjamurnya ujaran kebencian, saling hina dan hujat belakangan ini disebabkan oleh ketiadaan pemahaman netizen mengenai cara penggunaan media yang baik. Warganet lupa bahwa sekalipun mereka bersosial lewat dunia maya, tetapi efek yang ditimbulkan akan sangat nyata. Fakta ini menunjukkan bahwa bahwa perlu adanya gerakan literasi media oleh netizens agar dapat memanfaatkan internet secara positif, sehingga mempermudah kehidupan nyata. Manfaat internet sebagai media komunikasi dan informasi, sebagai media bisnis, dan sosialisasi dan aspirasi antara rakyat dan penguasa tentu harus dijaga, agar media baru yang diharapkan melahirkan budaya baru yang lebih beradab bisa terwujud.

Literasi media sering disamakan dengan pendidikan media (media education). Akan tetapi, sesungguhnya keduanya tidaklah sama (Tamburaka, 2013: 11).Literasi lebih kepada kemampuan yang secara efektif dan efisien memahami dan menggunakan berbagai bentuk komunikasi di media massa. Hal ini senada dengan yang dikemukan oleh J. Stanley Baran (2011: 24) bahwa kemampuan dan keahlian sesorang sangat penting dalam proses komunikasi massa.Lebih lanjut, Art Silverblatt, (dalam Tambaruka, 2013: 12), mengemukakan elemen-elemen literasi yang perlu diperhatikan: 1)Kesadaran akan dampak media pada individu dan masyarakat. 2) Pemahaman atas proses komunikasi massa. 3) Pengembangan strategi untuk menganilisis dan mendiskusikan pesan media. 4) Kesadaran atas konten media sebagai sebuah teks yang memberikan pemahaman kepada budaya kita dan diri kita sendiri. 5) 
Pemahaman kesenangan, pemahaman dan apresiasi yang ditingkatkan terhadap konten media.

Jika jurnalis profesional memiki kode etik jurnalistik (KEJ) dalam menjalankan tugas kewartawanannya, maka tidak dengan netizen sebagai jurnalis. Dalam konteks ini, citizen jourlism dituntut untuk bisa berjalan berdasarkan role, norma, dan etika yang berjalan pada masing-masing masyarakat. Karena pada prinsipnya bermain media sama halnya bersosial dalam dunia nyata. Oleh sebab itu, para netizen dituntut untuk melek media, agar dapat menjalankan aktivitas jurnalisme dengan baik dan benar.

Untuk mendapatkan kemampuan melek media, setidaknya ada beberapa prinsip etika yang harus dipahami. Rincian prinsip-prinsip yang dipedomani dalam etika jurnalisme yang utama adalah: pertama, akurasi. Prinsip akurasi berarti substansinya, fakta-faktanya, dan penulisannya benar, berasal dari sumber yang otoritatif dan kompeten, serta tidak bias.Kedua, independensi dan objektivitas (sering juga disebut balance). Prinsip objektivitas, berarti harus bebas dari obligasi atau kepentingan apa pun selain hak publik untuk mengetahui informasi, serta menghindari conflict of interest baik yang nyata maupun yang dipersepsikan. Ketiga, fairness, yaitu peliputan yang transparan, terbuka, jujur dan adil yang didasarkan pada dealing yang langsung (transparent, open, honest, and fair coverage based on straight dealing). Integritas berarti baik jurnalis maupun media menjaga ketat keutuhan prinsip yang mereka junjung dari segala kemungkinan penyimpangan sekecil apa pun. Keempat, akuntabilitas kepada publik, yaitu mengharuskan para jurnalis untuk senantiasa akuntabel dalam proses dan produk yang dihasilkan dalam melakukan aktivitas jurnalisme (Nasution, 2015: 9-10).

Kelima, humanitas dan solidaritas, yaitu tidak berbuat sesuatu yang langsung, disengaja merusak (damage) orang lain, meminimalisir cedera, berpikir luas (openminded) dan mempertimbangkan (thoughtful), menghormati hak-hak publik (rights of the public) dan kualitas moral dari jurnalisme itu sendiri (Nasution, 2015: 114).

Selain prinsip jurnalisme yang umum harus diketahui oleh jurnalis itu, diperlukan etika untuk menjaga perilaku netizen dalam bermedia ria, terlebih bermedia sosial.Hal ini diperlukan karena tindakan manusia ditentukan oleh macammacam norma. Etika menyelidiki dasar semua norma moral. Dalam etika biasanya dibedakan antara etika deskriptif dan etika normatif. Etika deskriptif memberi gambaran dari gejala kesadaran moral, dari norma dan konsep-konsep etis. Etika normatif tidak berbicara lagi tentang gejala, melainkan tentang apa yang sebenarnya harus merupakan tindakan manusia (Mufid, 2009: 175).

Netiket adalah etika berinternet, berasal dari dua kata yang dijadikan satu yakni networks dan etiquette, maka jadilah netiquette dan untuk mudahnya dibahasa indonesiakan menjadi netiket. Kata tersebut lahir dari kehadiran internet, artinya sebelum adanya internet kata tersebut memang tidak dikenal. Kata tersebut mengartikan perilaku sesuai etiket saat tersambung dengan jaringan internet, entah itu saat seseorang berinteraksi di forum mailing list, situs pertemanan, 
mikroblog maupun blog. Sejatinya memang ada etiket yang wajib dipegang oleh siapapun yang berada di jaringan internet saat mereka berinteraksi (Nugraga, 2012: 117).

Etiquette dapat diartikan sebagai tiket yang harus dimiliki seseorang untuk masuk ke dalam suatu komunitas, dalam konteks ini, merupakan standar aturan yang harus dimiliki untuk masuk ke dalam suatu jaringan atau masyarakat di dunia virtual. Pada intinya netiquette merupakan etika berinternet sekaligus perilaku sosial yang berlaku di dunia online (Nasrullah, 2014: 122). Etika berinternet diperlukan oleh warga/netizen (internet user), karena pengguna media internet beragam. Keragaman latar belakang bahkan kultural dapat menimbulkan perdebatan, konflik bahkan permusuhan.

Sopan santun di internet atau etiket sangat diperlukan dalam interaksi warga, di sini netizen harus menghindari trolling dan flaming. Trolling diartikan sebaga seseorang yang memposting tulisan atau pesan menghasut dan tidak relevan dengan topik yang dibicarakan. Tujuannya adalah memprovokasi dan memancing emosi para pengguna internet agar jalannya diskusi yang tengah berlangsusng menjadi kacau. Pelaku trollingini disebut troller.Upaya yang mirip dengan trolling adalah flaming. Flaming dikenal juga sebagai bashing, diartikan sebagai interaksi yang saling bermusuhan dan saling menghina antara pengguna internet. Sebagaimana trolling, flaming sering menggunakan kata-kata kotor dan tidak senonoh saat menggunakan aktivitas forum. Flaming bisa terjadi untuk diskusi apa saja, apakah itu isu di dunia nyata soal politik, agama, filsafat yang dibawa ke media internet (Nugraha, 2012: 140).

Etika berinternet diperlukan agar setiap netizen ketika berada di dunia virtual memahami hak dan kewajibannya sebagai warga negara dunia virtual. Dalam suatu komunitas, contoh dalam grup yang ada di media sosial Facebook, ada ketentuan yang harus disepakati pengguna ketika bergabung dalam grup ini. Contoh lainnya, saat pengguna membuat akun di fasilitas yang disediakan, misalnya akun di media sosial, akun e-mail, dan akun blog. Sebelum pengguna bisa menggunakan fasilitas akun tersebut, ada ketentuan yang semestinya dipahami oleh pengguna terkait apa saja yang diperkenankan, apa yang tidak, sampai pada ketentuan hukum jika melanggar (Nasrullah, 2014: 124).

Para pengguna media sosial dalam berinteraksi sudah sepatutnya menjaga etika berkomunikasi dengan sesama pengguna media sosial. Setidaknya para nitizen yang masuk dalam pusaran arus komunikasi dimedia sosial memiliki bentuk tanggungjawab moral dari komunikasi yang diolahnya untuk selanjutnya disebar dalam ruang publik. Para nitizen atau warga media sosial sebagai makhluk sosial yang memiliki kultur dalam kehidupannya dan dan sebagai bentuk membangun komunikasi yang sehat harus memahami bagaimana memanfaatkan penggunaan media tidak saja hanya menggunakan tetapi harus ada pemahaman tentang etika mengkomunikasikan maksud dan tujuan di ruang media sosial sebagai warga yang cerdas dalam berkomunikasi (Astuti, 2013: 215). 
Penerapan netiket prinsipnya sama menjalankan sopan santun atau etika berkomunikasi pada umumnya, hanya saja ranahnya di dunia maya, yaitu dalam memberikan komentar atau menanggapi penulisan, percakapan sebagai bentuk kebebasan berekspresi dalam ruang demokratisasi. Tetapi menggunakan kebebasan berekspresi ada ketentuan norma dalam kehidupan itu meski di ruang maya yaitu tetap menggunakan kalimat yang cerdas dalam mengekspresikan diri atas komentar dan percakapan, seperti halnya nyinyir, mendiskreditkan seseorang, bahkan sampai bahasa yang sarkatis, yang seharusnya dihindari karena melanggar ketentuan etika berperilaku termasuk dalam etika berkomunikasi (Astuti, 2013: 215).

Etika Komunikasi adalah cerminan dari kepribadian seseorang, dalam menunjukan karakter dirinya dari mana mereka tumbuh dan berkembang dan lingkungan yang mempengaruhi perkembangan komunikasinya, maka sebaiknya dan sangat penting warga dunia maya cerdas dalam mengolah kepribadiannya untuk menegakan etika komunikasi sebagai pribadi yang memiliki keberadaban (Astuti, 2013: 216).

\section{Dakwah Era Global dan Peran}

\section{Ulama di Media Sosial}

Islam merupakan agama dakwah baik secara teoritis maupun praktis sebagai agama dakwah, kedudukan Islam melebihi agama-agama dakwah yang lain dan ini disebabkan oleh klaim Islam sendiri bahwa ia merupakan wahyu terakhir dan penyempurna dari agama-agama sebelumnya terutama Yahudi dan Nasrani. Ismail Raji Al Faruqi (1986: 187-188) menegaskan bahwa dakwah bukan saja merupakan keharusan melainkan tugas terbesar kaum muslim yang harus ditunaikan, karena itu, dapat dipahami jika semangat untuk menyampaikan dan memperjuangkan kebenaran Islam terus membara dalam jiwa muslim. Bahkan cita-cita hidup seorang muslim yang taat adalah membawa manusia ke dalam suatu kehidupan yang Islam dapat diterima dan menjadi agama (system hidup seluruh umat di dunia). Dakwah adalah cara untuk merealisasikannya.

Dakwah menurut Syaikh Ali Mahfudz dalam kitabnya, Hidayatul Mursyidin adalah mendorong manusia agar berbuat kebaikan dan mengikuti petunjuk (alhidayah), menyeru mereka berbuat kebaikan dan mencegah dari kemungkaran, agar mereka mendapat kebahagiaan di dunia dan akhirat (Mahfud: tt: 17). Sedangkan Muhammad $\mathrm{Abu}$ al-Fath al-Bayanuni memberikan ta'rif bahwa dakwah adalah menyampaikan dan mengajarkan agama Islam kepada seluruh manusia dan mempraktekkannya dalam kehidupan nyata (al-Bayanuni: 1993: 17). Agar Islam dapat terus menyebar dan meresapi jiwa dan raga para pengikutnya, maka dakwah harus terus dikembangkan sesuai dengan perkembangan zaman.

Berkaitkan dengan kompleksitas perubahan era informasi dan pascaindustri, banyak masalah yang harus dihadapi dan diselesaikan oleh dakwah jika tidak ingin eksistensinya tenggelam dalam perubahan-perubahan yang sedang dan akan berlangsung. M. Nafis (2005: 10-11) menyatakan bahwa perlu adanya 
pencarian format dan konstruk dakwah yang efektif dan operasional baik pada struktur, materi, pendekatan dan metodenya. Sedangkan konstruk dakwah sangat dipengaruhi oleh kualitas interaksi antara pembakuan ideologi dasar dengan kreatifitas para pendukung dakwah dalam menampilkan ideologi tersebut sesuai dengan struktur dan pola kultur yang berkembang. Oleh sebab itu, konstruk dakwah harus mendasarkan diri pada asas konsistensi, kreatifitas dan fleksibelitas yang tinggi. Dakwah harus dipahami bukan hanya dengan ceramah atau pidatopidato saja, tetapi dakwah merupakan segala aktivitas, baik dalam bidang keagamaan, ekonomi, sosial, pilitik, maupun kebudayaan yang tujuannya adalah untuk kebahagiaan dunia dan akhirat (Aziz, 2018: 222-223). Media massa adalah salah satu yang perlu dioptimalkan.

Pada level arus globalisasi yang dicirikan penggunaan media elektronik, komputer dan media cetak, redefinisi dakwah pada bidang-bidang tersebut perlu dilakukan. Seperti yang telah diuraikan sebelumnya bahwa difusi dan infiltrasi kebudayaan merupakan fenomena umum dalam era globalisasi. Oleh sebab itu bukan tidak mungkin bahwa dakwah dengan muatan-muatan doktrinalempiriknya akan terlibat dalam proses difusi dan infiltrasi kebudayaan tersebut. Hanya saja kemampuan dan kecakapan untuk memanfaatkan berbagai media dan sarana tersebut perlu ditangani secara serius dengan mengintensifkan pelatihan dan pengadaan prasarananya (jika dipandang mungkin). Meskipun tidak harus berarti bahwa media tradisional diterlantarkan (Nafis, 2005: 9).
Terdapat kesimpulan yang cukup kuat bahwa mekanisme dakwah masih tertatihtatih dan belum mampu mengimbangi tuntutan-tuntutan dasar era informasipasca industri-perubahan yang ada. Kesenjangan antara konstruk dakwah dengan realitas sosial demikian lebar (Achmad, 1983: 2-24). Solusi sering bersifat parsial, itupun tidak didasarkan pada analisis masalah aktual yang berkembang. Organisasi dakwah telah berkembang, tetapi masih bergerak terserak dan sedikit yang ditata dengan manajemen modern. Akibatnya media elektronik dan cetak tidak secara efektif digunakan untuk aplikasi dakwah dan pada akhirnya problematika yang berkembang terbengkalai dan tidak mendapatkan jawaban yang berarti (Nafis, 2005: 7).

Dengan tingkat kemajuan ilmu pengetahuan dan teknologi yang selalu mengasumsikan dinamika yang tak terbatas, maka tingkat manipulasi terhadap alam juga akan semakin luas dan mencapai kawasan-kawasan yang semula tak terbayangkan. Teknologi informasi dan jasa, yang oleh sebagian kalangan dikategorikan sebagai manifestasi budaya pasca modern (Johnson, 1986: 23), telah menghantarkan proses globalisasi semakin cepat dan sekaligus ketergantungan yang semakin akut.

Dengan kecanggihan teknologinya, media massa saat ini lebih memudahkan proses penyebaran dakwah. Paul Lazarsfeld dan Robert $\mathrm{K}$ Merton juga melihat media dapat menghaluskan paksaan sehingga tampak sebagai bujukan (Wiliam dan W. Jensen, 2008: 35). Sejalan dengan itu harus dipahami manfaat dan mudharat teknologi informasi 
dan komunikasi, serta secara sadar memanfaatkannya untuk mencapai tujuan kita, bukan tujuan-tujuan mereka (pembuat dan pencipta teknologi). Dengan kata lain, sebagai pengguna informasi baik sebagai subjek atau pun objek jangan sampai terjebak dengan kepentingankepentingan yang tersembunyi di balik kecanggihan media tersebut.

Dengan demikian tantangan para dai untuk berdakwah semakin tinggi, disaat akses terhadap pemanfaatan teknologi informasi dan komunikasi semakin terbuka akan tetapi dilain pihak profesionalisme lembaga dakwah dan para dai dituntut lebih baik, serta tantangan yang paling berat adalah dikala memanfaatkan media yang yang sudah menjadi industry yang profitable untuk tujuan dakwah, dibalik pesan-pesan yang disampaikan. Sebab pemanfaatan teknologi informasi dan komunikasi dewasa ini adalah suatu keniscayaan yang tidak mungkin diabaikan.

Seperti media internet yang akhirakhir ini perkembangannya sangat fenomenal memiliki pengaruh langsung yang sangat kuat kepada pembacanya. Internet mampu menggerakkan prilaku massa sesuai dengan arah yang dikehendakinya. Kenyataanya massa tidak memiliki daya apa-apa, sehingga karena kehalustajamannya itu, Jalaluddian Rakhmat melukiskannya ibarat seorang pasien yang tidak berdaya apa-apa setelah dimasuki sejenis serum melalui jarumkecil dalam tubuh (Rakhmat, 1988: 88).Jaringan sosial di dunia maya tersebut sangat potensial untuk dimanfaatkan sebagai sarana dakwah.

Ulama harus tetap menjalankan fungsinya sebagai pewaris para nabi

dengan melakukan dakwah yang tantangannya sangat kompleks. Media sosial menjadi salah satu alternatif media (wasilah) dakwah yang bisa dimaksimalkan, mengingat masyarakat Indonesia kini hampir-hampir 50\% menggunakan internet, terutama media sosial. Tentu ini menjadi ladang basah yang harus digarap oleh mereka, sekalipun dalam ladang itu banyak terdapa ular dan lintah yang senantiasa mengancam. Karena itu, diperlukan kesiapan lahir batin untuk menjalaninya.

Pada akhir 2016, empat orang dari berbagai daerah datang ke kediaman pengasuh Ponpes Raudlatut Thalibin, Ahmad Mustofa Bisri (akrab disapa Gus Mus) di Rembang, Jawa Tengah. Mereka minta maaf telah menghina di media sosial. Selain Gus Mus, Rais Syuriah PBNU KH Ma'ruf Amin telah memaafkan Boni Hargens yang telah mengunggah ulang foto pernikahan tahun 2014 lalu. Sebelumnya, Boni telah meminta maaf atas tindakannya tersebut. Dia mengaku salah: seharusnya menyimpan gambar, namun malah mempostingnya di Twitter (Detik.com, 28 November 2016).

Berkaitan dengan itu, Ahmad Mustofa Bisri menyebut para pemuda yang telah berkata-kata kasar kepadanya di medsos ini hanyalah salah pergaulan. Dia pun menyoroti bagaimana 'sakti'-nya medsos bisa mengubah orang-orang yang santun di dunia nyata menjadi buruk perilakunya di dunia maya. Oleh karena itu, Gus Mus mengemukakan beberapa hal yang perlu diperhatikan para netizen:

Kepada mereka ini dan semisal mereka bukan yang sengaja menjadikan sosmed sebagai sarana menebar kebencian dan kekacauan kalau boleh, aku 
menasihatkan agar:(1) menata kembali niat kita dalam menggunakan dan memanfaatkan Sosmed; (2) berhati-hati dan waspada beraktivitas di 'dunia maya' yang penuh tipuan; (2) jangan mudah tergiur dengan tampilan-tampilan menarik, biasakan tabayun dan meniliti rekam-jejak; (3) jangan tergesa-gesa membaca dan membagikan bacaan; (4) usahakan sekali-kali KopDar, agar bisa melihat Manusia dalam penampilan nyatanya (dalam hal ini, contohlah misalnya perkawanan maya dan nyata dari misalnya komunitas Adib Machrus, Pakdhe Tegoeh, Timur Suprabana, Zen Mehbob, Triwibowo Budi Santoso, Zaenal Maarif, dan mereka yang tidak hanya bersapaan di sosmed tapi juga bersilaturahmi di dunia nyata. Mereka guyub, penuh kasihsayang); (5) ingat sabda Rasulullah SAW "Innamal a'mãlu binniyãt... alhadits" dan "Min husni Islamil mar-i tarkuhu mã lã ya'ni". (Bisri, 2016).

Fakta di atas menunjukkan bahwa media sosial ibarat bara yang bisa digunakan untuk memasak sate, ikan, ayam, bebek, dll, akan tetapi juga bisa membakar segalanya. Oleh sebab itu, jika ulama terjun di media sosial, jangan sampai terjebak dalam fragmen-fragmen tertentu dan harus menjadi problem solver umat yang bermain media sosial. Proses ini merupakan dinamisasi dakwah dalam menjamu pergerakan zaman, sama halnya dengan dakwah memanfaatkan media radio dan televisi sewaktu awal keberadaanya. Social media di dunia maya sangat potensial untuk dimanfaatkan sebagai sarana dakwah. Tentu saja, para ulama tidak boleh melupakan dan mengabaikan tenaga-tenaga yang akan mengisi aktivitas dakwah di masjidmasjid, pondok pesantren, majelis taklim, dan sejenisnya yang selama ini sudah berjalan.

\section{PENUTUP}

Pada era informasi saat ini, yang menjadi penguasa dunia adalah mereka yang menguasai informasi dan perangkat teknologi informatika. Karena itu, saat ini berlomba-lombalah para penduduk bumi untuk menaklukannya. Saat ini internet telah melengkapi media lama (baca: konvensional), untuk tidak dikatakan menggantikan. Masyarakatpun beramairamai menyerbu internet dengan berbagai kompleksitasnya. Hal ini telah menguatkan budaya jurnalisme warga yang telah muncul beberapa tahun sebelumnya. Terbukanya akses terhadap informasi yang disediakan oleh citizen journalism, diyakini akan dapat memberikan manfaat besar bagi masyarakat.

Namun, saat ini tidak bisa dielakkan bahwa dampak negatif internet sebagai media komunikasi telah menjangkiti sebagian besar penggunanya, termasuk di Indonesia. Banyak dijumpai hate speech atau ujaran kebencian dari para pengguna internet, terutama socialmedia. Ini kemudian telah menggeser fungsi dari sosmed yang awalnya sebagai media sialturrahmi berganti sebagai media "nyinyir".Sejatinya memang ada etiket yang wajib dipegang oleh siapapun yang berada di jaringan internet saat mereka berinteraksi. Namun, karena ketidakpahaman atau keterbatasan pengetahuan netizen mengenai etika dan prinsip yang harus digunakan dalam 
bermedia sosial, maka dampak buruk

terhadap penggunanya tidak bisa dihindari.

Oleh sebab itu, diperlukan literasi media yang menyeluruh dan kontestual untuk menjelajah seluruh netizen agar memahami netiket di media baru. Para penggiat literasi media dan akademisi yang fokus pada kajian media dan budaya harus menggelorakan gerakan literasi media pada masyarakat dunia maya. Tidak kalah pentingnya adalah peranan ulama untuk turut serta menjadi "pendobarak" literasi media dalam rangka menjaga dan merawat umat. Lebih jauh lagi, social media bahkan harus dimanfaatkan sebagai sarana dakwah. Para ulama yang terjun di dunia maya haruslah mempersiapkan diri secara lahir dan batin, agar tidak justru terjebak dalam kubangan berbahaya tersebut. 
Netizen Jurnalisme Dan Tantangan Dakwah...hal. 121-140

\section{DAFTAR PUSTAKA}

Achmad, Amrullah dkk., Dakwah Islam dan Perubahan Sosial, (Yogyakarta: PLP2M, 1983).

al- Faruqi, Ismail Raji, dan Lois Lamya alFaruqi, The Cultural Atlas of Islam, (New York: Macmillan Publishing Company, 1986), hlm. 187-188

al-Bayanuni, Muhammad Abu al-Fath, al Madkhal ila 'Ilm al Da'wah, (Beirut: Muassaah al-Risalah, 1993).

Arsyad, A. Media Pembelajaran, (Jakarta: Rajawali Pers, 2002).

Aziz, Mokhamad Abdul, Etika Komunikasi Verbal dalam al-Qur'an, (Semarang: LP2M UIN Walisongo, 2014).

Aziz, Mokhamad Abdul, Korupsi dan Ancaman Demokrasi, (Yogyakarta: Idea Press, 2018).

Bajari, Atwar, dan Sahala TS, Komunikasi Kontekstual: Teori dan Praktik Komunikasi Kontemporer, (Bandung: Remaja Rosdakarya, 2011).

Baran, J. Stanlaey, Pengantar Komunikasi Massa: Literasi Media dan Budaya, (Jakarta: Salemba Humanika, 2011).

Bungin, Burhan, Metode Penelitian Kuantitatif, (Jakarta: Kencana, 2011).

Burton, Graeme, Media dan Budaya Populer, (Yogyakarta: Jalautra, 2012).

Creeber G. dan Martin, Digital Cultures, (New York: Open University Press, 2009).
Hermawan, Media Pembelajaran SD, (Bandung: Upi Press, 2007).

Homes, David, Teori Komunikasi: Media, Teknologi, dan Masyarakat, (Yogyakarta: Pustaka Pelajar, 2012).

Johnson, Doyle Paul, Teori Sosiologi Klasik dan Modern, I, terj. Robert M.Z. Lawang (Jakarta:PT. Gramedia, 1986).

Kuswarno, Engkus, dkk, Komunikasi Kontekstual, (Bandung: Remaja Rosdakarya, 2010).

Lievrouw, L.A. dan Sonia Livistone, The Handbook of New Media, (London: SAGE Publications, 2006).

Mahfudz, Syekh Ali Hidayatul Mursyidin, (Libanon: Darul Ma'rifat, tt).

McQuail, Dennis, Mass Communication Theory (London : Stage Publication Ltd, 2009).

Mondry, Pemahaman Teori dan Praktik Jurnalistik, (Bogor: Ghalia Indonesia, 2008).

Mufid, Muhammad,Etika dan Filsafat Komunikasi, (Jakarta: Kencana, 2009).

Nasrullah, Rully, Teori dan Riset Media Siber (Cybermedia), (Jakarta: Kencana, 2014).

Nasution, Zulkarimein, Etika Jurnalisme: Prinsip-prinsip Dasar, (Jakarta: Raja Grafindo Persada, 2015).

Nugraha, Pepih,Citizen Journalisme, (Jakarta: Buku Kompas, 2012). 
Rakhmat, Jalaluddin, Islam Aktual: RefleksiSosial Seorang Cendekiawan Muslim, (Bandung: Mizan, 1998).

Rakhmat, Jalaluddin, Psikologi Komunikasi, (Bandung: PT Remaja Rosdakarya, 1988).

Rivers, L. Wiliam dan W. Jensen, Jay, Media Massa dan Masyarakat Modern, (Jakarta: Prenada Grup, 2008).

Ruben, Brent dan Lea P. Stewart, Communication and Human Behavior, (USA: Viacom Company, 1998).

Samantho, Ahmad Y, Jurnalistik Islami: Panduan Praktis bagi Para Aktivis Muslim, (Jakarta: Harakah, 2002).

Subandi Ibrahim, Idi dan Bachrudin Ali Akhmad, Komunikasi dan Komodifikasi: Mengkaji Media dan Budaya dalam Dinamika Globalisasi, (Jakarta: Yayasan Obor Indonesia, 2014), hlm. 3

Sugihartati, Rahma, Perkembangan Masyarakat Informasi dan Teori Sosial Kontemporer, (Jakarta: Kencana, 2014).

Suhelmi, Ahmad, Pemikiran Politik Barat, (Jakarta: Penerbit Gramedia Utama, 2007).

Suratman, Winarno,Pengantar Penelitian Ilmiah Dasar, (Bandung: Tarsito, 1985).

Syah, Sirikit Membincang Pers, Kepala Negara, dan Etika Media, (Jakarta: Elex Media Komputindo, 2014).

Toffler, Alvin. The Third Wave. (London: Pan Books Ltd in association with
William Collins Sons \& Co. Ltd, 1980).

Tamburaka, Apriadi, Literasi Media: Cerdas Bermedia Khalayak Media Massa, (Jakarta: Rajawali Pers, 2013).

Vivian, John, Teori Komunikasi Massa, Cetekan II (Jakarta: Prenada Media Group, 2015).

Wynants dan Cornelis, How Open Is the Future?: Economic, Social \& Cultural Scenarios Inspired by Free \& Open-Source Software, (USA: Crosstalks, 2008).

\section{Jurnal dan Artikel Ilmiah:}

Alamiyah, Syifa Syarifah, "Peluang dan Tantangan Citizen Journalism di Indonesia”. Jurnal Ilmu komunikasi, Vol. 7, No.2, Oktober 2015).

Astuti, Sri Ayu, "Media Sosial Sebagai Ruang Publik", KANAL, Vol. 1, No. 2, Maret 2013, Hal. 111-220.

Fitri, "Etika Komunikasi Citizen JournalismDi Media Internet Perspektif Islam:Analisis Konten Topik Pilihan Demo 4 November 2016pada Blog kompasiana.com", Jurnal Ilmu Dakwah, Vol. 36(2) 2016 EISSN 2581-236X, Hal 243269.

Hauben, Ronda, "Netizen Journalism: The Emergence of New Forms of News that Can Improve the Policy Making Process", (http://www.columbia.edu/ hauben/ ronda2014/May2.pdf), hlm. 4. Diakses pada 14 Januari 2017 pukul $22.30 \mathrm{WIb}$. 
Netizen Jurnalisme Dan Tantangan Dakwah...hal. 121-140

Ika Setyani, Novia, "Penggunaan Media Sosial Sebagai Sarana Komunikasi Bagi Komunitas: (Studi Deskriptif Kualitatif Penggunaan Media Sosial Twitter, Facebook, dan Blog sebagai Sarana Komunikasi bagi Komunitas Akademi Berbagi Surakarta)", (Jurnal Komunikasi Universitas Sebelas Maret D1210054-2013).

Nafis, M., "Transformasi Sosial dan Dakwah di Era Milenium III", (Teologia Volume 16, Nomor 2, Juli 2005).

Touri, M. "News Blogs: Strengthening Democracy Through Conflict Prevention." In Aslib Proceedings Vol. 61, No. 2, pp. 170-184, (Emerald Group Publishing Limited, 2009, March).

\section{Surat Kabar atau Portal Berita}

Harian Amanah, "Ulama Siap Memanfaatkan Medsos”, 29 Desember 2016).

Detik.com, "Cerita Kearifan Ulama Saat Dihina di Medsos, dari Gus Mus hingga Ma'ruf Amin”, 28 November 2016, (https://news.detik.com/berita/d3356210/cerita-kearifan-ulama-saatdihina-di-medsos-dari-gus-mushingga-maruf-amin/3), diakses 13 Januari 2017 pukul 17.30 Wib.

Mustafa Bisri, "Jum'at dan Silaturahmi", Facebook.com, 27 Novemer 2016 (https://www.facebook.com/simbah. kakung/posts/10202832581691128), diakses 13 Januari 2017 pukul 17.35 Wib.

Okezone.com, "Ditangkap Terkait Makar, Hatta Taliwang Dijerat UU ITE",8 Desember 2016), diakses dari http://news.okezone.com/read/2016/ 12/08/337/1561955/ditangkapterkait-makar-hatta-taliwang-dijeratuu-ite pada 14 Januari 2017 pukul $15.40 \mathrm{Wib}$. 